\title{
Short Communication: Antimicrobial properties in cloacal fluid of olive ridley sea turtle (Lepidochelys olivacea)
}

\author{
RATIH NOVITA PRAJA ${ }^{1, \bullet}$, ADITYA YUDHANA ${ }^{2}$, WIYANTO HADITANOJO ${ }^{3}$, VIVI OKTAVIANA ${ }^{3}$ \\ ${ }^{1}$ Division of Microbiology, Faculty of Veterinary Medicine, Universitas Airlangga. C Campus, Jl. Mulyorejo, Surabaya 60115, East Java, Indonesia. \\ Tel.: +62-31-5992785, "email: ratihnovitapraja @ fkh.unair.ac.id \\ ${ }^{2}$ Division of Parasitology, Faculty of Veterinary Medicine, Universitas Airlangga. C Campus, Jl. Mulyorejo, Surabaya 60115, East Java, Indonesia \\ ${ }^{3}$ Banyuwangi Sea Turtle Foundation. Jl. Wahid Hasyim, Banyuwangi 68416, East Java, Indonesia
}

Manuscript received: 13 July 2021. Revision accepted: 12 August 2021.

\begin{abstract}
Praja RN, Yudhana A, Haditanojo W, Oktaviana V. 2021. Short Communication: Antimicrobial properties in cloacal fluid of olive ridley sea turtle (Lepidochelys olivacea). Biodiversitas 22: 3671-3676. There were several speculations regarding the main purpose of sea turtle cloacal fluid, such as lubrication during egg deposition, which could help reduce egg speed as they are dropped in nesting sand, or contain antimicrobial properties to protect their eggs from pathogenic microorganisms. However, the exact purpose of this fluid which is mucous-like in consistency remains unknown. This study aimed to identify antimicrobial properties in the cloacal fluid of olive ridley sea turtles. Cloacal fluid samples were collected during nesting season in Banyuwangi City coastal areas, East Java Province, Indonesia. Moreover, the Kirby-Bauer diffusion disk method recorded antimicrobial properties and tested against several bacterial colonies collected from sand in natural nesting chambers. This preliminary study also concluded that antimicrobial properties were recorded when presented against several bacteria colonies from natural nesting sands namely Escherichia coli, Salmonella spp., and Bacillus spp. Furthermore, the present study should be expanded to include other bacteria and fungi colonies. In addition, results from the present study could be used to develop methods in creating antibiotics similar to those found naturally in natural nesting areas to prevent microorganism contamination and globally increase hatchling success, which has a greater impact to support sea turtle conservation efforts as endangered species.
\end{abstract}

Keywords: Antimicrobial properties, biodiversity, cloacal fluid, olive ridley

\section{INTRODUCTION}

The olive ridley sea turtle (Lepidochelys olivacea) is threatened by fisheries bycatch, habitat degradation, and the unsustainable harvest of eggs and is listed by the IUCN as a vulnerable species (Abreu-Grobois et al. 2020). Bacteria and fungi contamination have been reported to reduce the hatchling success of sea turtle nests worldwide (Bezy et al. 2015; Caron et al. 2018; Gifari et al. 2018; Candan and Candan 2020; Hoh et al. 2020). Several bacterial species have even been shown up to $100 \%$ nest mortality (Booth and Dustan 2018). Several studies have suggested that sea turtle embryo mortality is associated with the high microbial load resulting from the decomposition of contaminated eggs during subsequent nesting events (Neves et al. 2015; Hoh et al. 2019; Gleason et al. 2020). In addition, nutrient loads and bacterial abundance in the sand at sea turtle nesting beaches are much higher than non-nesting beaches (Peay et al. 2016).

Therefore, several studies reported bacteria and fungi have been cultured and isolated from nest sand and unhatched eggs and the cloacal fluid of nesting females (Rosado-Rodriguez and Maldonado-Ramirez 2016; Bezy et al. 2015). However, the literature on the detailed mechanism of infection in sea turtle eggs by microbes remains unknown. Microbial infection was traditionally assumed to be opportunistic and limited laboratory studies found no significant effect of bacteria or fungi on the hatchling production of olive ridley sea turtle eggs (Bezy et al. 2015; Smyth et al. 2019). In addition, several studies also suggested that the observed increase in hatching success in nests below the high tide line may be due to natural tidal washing, which could remove microbes that are intolerant to saltwater. In contrast, bacterial richness and diversity may increase in the low, middle, and high zones of beach with increasing nest density, probably due to the less stable osmotic environment caused by the tides (Neves et al. 2015; Hoh et al. 2019).

Moreover, it has been suggested that the fluid which ovipositing females deposit with the eggs may contain antimicrobial properties, providing protection mechanism to developing embryos from potential pathogens in the sand (Soslau et al. 2011). These clear liquids are made up of glycoproteins secreted from the cloaca, and coat the eggs as they are deposited into the egg chamber. The exact purpose of this fluid remains unknown. However, one of its purposes is most likely to be lubrication during egg deposition, it has also been assumed that the purpose of the fluid is to suspend the eggs in a state of hypoxia to prevent embryos from reaching the stage of development where they are sensitive to movement-induced mortality as the rest of the clutch eggs are formed (Rafferty and Reina 
2012). Glycoprotein cloacal secretions also exist in freshwater turtles and when they are absent, the eggs hatching success may be reduced. Lee (2020) reported that mucus plays role against pathogenic infections such as bacteria, which indicates the natural defense mechanism in the environment. Furthermore, Phillott and Parmenter (2012) discovered that cloacal fluids can decrease fungal growth for several days, thus if the fluid can defend against fungi, it may also be able to defend against bacterial growth.

The mucus of other organisms, such as fish, amphibians, and humans have been proven to contain antifungal and antibacterial properties (Dawson 2011). Moreover, several studies reported that the majority of skin mucus from fish such as Caspian (Rutilus frisii kutum), Indian carp (Catla catla), carp (Cyprinus carpio), and Hypophthalmichthys nobilis showed antibacterial effects (Raj et al. 2011; Tyor and Kumari 2016; Adel et al. 2018; Abbas et al. 2020). It is possible that similar proteins of antimicrobial could be present in cloacal fluid, thus having similar defenses to protect eggs, especially at the beginning of incubation when embryos are most vulnerable to bacterial infection. To determine the nature of the defense mechanism imparted by the cloacal fluid, the purpose of this study was to identify any antimicrobial properties in the cloacal fluid of olive ridley sea turtle.

\section{MATERIALS AND METHODS}

\section{Sample collection}

Cloacal fluid samples were collected from every turtle found before starting laying her eggs in their natural nest area organized by Banyuwangi Sea Turtle Foundation (BSTF), East Java Province, Indonesia (114.369227 E; 8.219233 S). Moreover, to obtain an uncontaminated fluid sample, aseptic care was taken to avoid bacterial contamination from nesting sand. Due to limitation conditions in field, cloacal fluid samples were taken and divided into four batches. First, sand samples were collected from nine different natural nests used by turtles to lay their eggs. For the next process, all obtained samples were placed in a transport medium (Becton-Dickinson, Maryland, USA), and kept on ice or $4^{\circ} \mathrm{C}$ until processing within 24 hours.

Furthermore, thawed sand samples were processed by adding $2 \mathrm{~mL}$ of sterile distilled water and shaking for 30 seconds manually. To obtain selective Gram-negative bacteria, MacConkey agar was used as the enrichment medium, spread-plated with $100 \mu \mathrm{L}$ of the water from the sand suspension mixture and then quadrant-streaked. The compounds such as crystal violet and bile salts in MacConkey agar inhibit the growth of Gram-positive bacteria, and the presence of lactose and the $\mathrm{pH}$ indicator neutral red identifies colonies as lactose fermenters or nonfermenters, which aids in colony identification (Soslau et al. 2011).

\section{Bacterial identification}

Preliminary bacterial identification from the nesting sand samples was completed on-site after purified using the standard confirmed bacteriological methods, Analytical Profile Index (API) strips (BioMerieux, Marcy-I'Etoile, France). API strips were inoculated with a suspension of a bacterial colony in a sterile solution and incubated using standard bacteriological method at $37^{\circ} \mathrm{C}$ for 24 hours. However, if there were no changes in the inoculated strip after incubation for 24 hours, the strips continued to incubate for another 24 hours, as indicated by Bio-Merieux. Furthermore, samples were sent to Laboratory of Veterinary Microbiology, PSDKU Banyuwangi, and then each sample was cultured into nutrient agar, MacConkey agar, eosin methylene blue agar, and Salmonella-Shigella agar (Remel, Lenexa, KS, USA). The bacterial colonies were obtained from each plate, then taken for further identification using Gram-staining methods. Bacterial identification methods in the laboratory were completed using semiautomated API 20 and API Staph systems (BioMerieux) with IdBact software. During the identification process, bacterial isolates that were positively obtained from sand samples were then used for further diffusion tests to investigate the antimicrobial properties of cloacal fluid samples.

\section{Agar diffusion test}

The diffusion test was done using Kirby-Bauer disk diffusion method. A total of $75 \mu \mathrm{l}$ from each cloacal fluid is dropped on a paper disk, and leave it for 15 minutes until it completely absorbs. During the previous process, MuellerHinton agar (MHA) was prepared on a Petri dish. The bacterial suspension was taken with a $0.2 \mathrm{ml}$ sterile pipette and then poured on MHA and scattered with a bent glass stirrer. The plates were allowed to stand for 20 minutes so the bacteria stick totally. Paper disk containing cloacal fluid was placed on the surface of MHA using sterile tweezers, then incubated for 24 hours at $37^{\circ} \mathrm{C}$. The diameter of inhibitory zones that were formed in MHA, then measured by using Vernier calipers. Inhibition zones that formed slightly around paper disc were measured in millimeters $(\mathrm{mm})$ unit length within vertical and horizontal areas.

\section{RESULTS AND DISCUSSION}

Three different bacterial colonies were identified from nesting sand samples based on the API test and identification using standard bacteriological examination methods. The three bacteria belonging to these colonies were Escherichia coli, Salmonella spp. and Bacillus spp. Macroscopically, all of the colonies were round in shape and different in terms of color. E. coli colonies were metallic green, Salmonella spp. colonies were black, and Bacillus spp. colonies were white in each agar plate. Gram staining showed that these colonies were identified as Gram-negative bacteria (i.e., Escherichia coli and Salmonella spp.). Gram-positive bacteria were also identified as Bacillus spp. Microscopically, the cell shape of those three different bacteria was rod-shaped with different sizes. E. coli was the most frequent among other bacteria isolated from sand samples. Moreover, all colonies 
were used for diffusion test which possibly inhibited with cloacal fluid samples. Results from the Kirby-Bauer disk diffusion test run indicated antimicrobial properties in the cloacal fluid of olive ridley sea turtles at Banyuwangi coastal area when applied to Mueller-Hinton agar containing E. coli, Salmonella spp. and Bacillus spp. respectively. The zones formed on the plates from the cloacal fluid were not perfect circles if compared to KirbyBauer disk diffusion which was completed with antibiotics and incubated at $37 \mathrm{oC}$ for 24 hours. Furthermore, zone diameters were measured twice for vertical and horizontal areas to analyze the results, and the average was recorded (Table 1). The results also show that Bacillus spp. colonies were inhibited the most, proved by measured diameters were widest $( \pm 7-8 \mathrm{~mm}$ on average) among the other colonies (Figure 1). Cloacal fluid was also recorded to have antimicrobial properties against E. coli and Salmonella spp. However, the zones formed among those two different bacteria were not significantly different $( \pm 6 \mathrm{~mm}$ on average).

The lack of antimicrobial properties could be due to the majority of bacterial species used as samples in these studies was commonly present within the nesting environment, thus resistance mechanism to the cloacal fluid may have already built up for these species. Indeed, Bacillus spp. and coliform bacteria such as E. coli and Enterobacter cloacae were frequently found in unhatched eggs with $E$. coli also isolated from a natural nesting chamber. Other bacteria such as Staphylococcus aureus are also often found on human skin and nowadays Banyuwangi coastal area is a popular tourist destination in Indonesia. Moreover, sea turtles may have come into contact with multiple strains of $S$. aureus species, which also need further studies due to potentially building up resistance mechanism to cloacal fluid. Among others bacteria species, Salmonella spp. was categorized as the most pathogenic bacteria. In addition, the presence of Salmonella spp. in nesting chamber due to fecal contamination from domestic mammals. Since samples are well-known as tourism objects, there were many cats and dogs around that possibly laid their stool near-natural nest. Furthermore, those domestic animals not only stray but also pets, also there were local horses that were commonly used as horseriding objects. Therefore, the present study has different results from the previous study conducted by Keene
(2012), which tested the antimicrobial properties of cloacal fluid against Pseudomonas aeruginosa. In addition, the different results were recorded possibly because different bacteria isolates used in the study were also different. Bacterial isolate sources in the present study were from natural nesting chambers, whereas the previous study collected from unhatched eggs.

Antimicrobial properties in cloacal fluid may be present in various populations or individuals; also, dilution methods are more suited for preliminary study for antimicrobial properties, as supported by the previous results from Dawson (2011). The presence of antimicrobial properties is possibly present in three initial samples in this study that were used to test the methods. It is also possible that antimicrobial properties can present and record different results when tests with different bacteria or fungi species. Previous study in Australia found 97\% of the hatched eggs were infected with microorganisms, and concluded there would be no need for defenses against bacterial species that are not potentially pathogenic, and perhaps cloacal fluid only targeted those that are pathogens to embryos (Dawson 2011). However, it is unclear, if the fluid can defend eggs against microorganisms once it dries because of natural processes. Other antimicrobial proteins, such as those found in the albumen of eggs, have been proven to defend against microorganisms.

Moreover, the lowest concentration of bacteria was found in the albumen of the eggs, and this process was related to this observation regarding antimicrobial chemical defense properties of the albumen proteins (Blasi et al. 2020; Phillot and Parmenter 2012). The present study assumed that cloacal fluid has a similar defense mechanism to protect eggs, especially at the beginning of the incubation process when embryos are most vulnerable to contamination of microorganisms. There are various ways in which sea turtle cloacal fluids could obtain antimicrobial properties, first method is through the use of peptides, a common method utilized by plants. Second method is through mutualistic relationships with other bacteria, as occurs in the human cervical mucus, where antibodies passed which can then be passed from mother to offspring, a method often used in mammals. Moreover, it can be gained from their diet since many sea turtle food organisms produce antimicrobial compounds (Pelegrini et al. 2011; Torow et al. 2017; Dawson 2011).

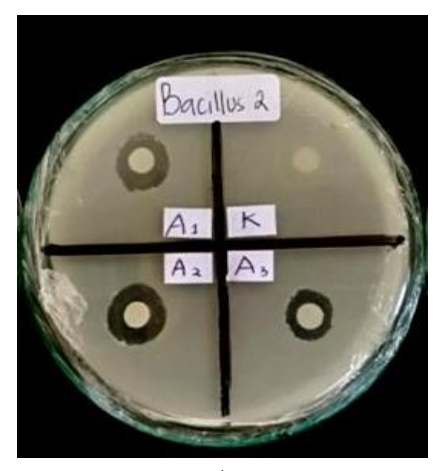

A

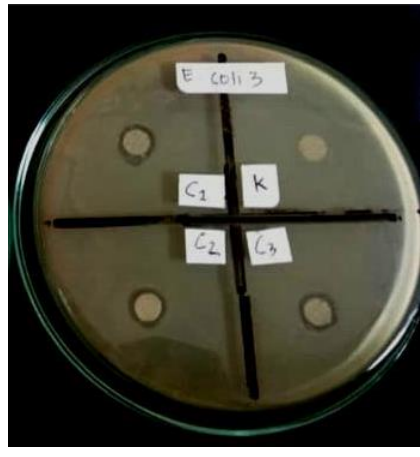

B

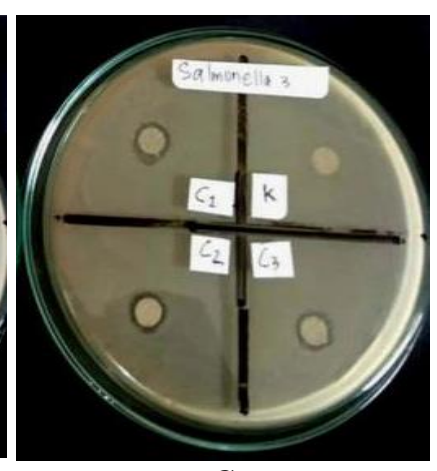

C

Figure 1. Kirby-Bauer experiment for cloacal fluid from olive ridley sea turtle incubated for 24 hours at $37^{\circ} \mathrm{C}$ on Mueller-Hinton agar. The bacteria on each plate are A. Bacillus spp., B. Escherichia coli, C. Salmonella spp. 
Table 1. Results of Kirby-Bauer disk diffusion test with Escherichia coli, Salmonella spp., Bacillus spp. and olive ridley sea turtle cloacal fluid

\begin{tabular}{|c|c|c|c|c|c|}
\hline \multirow{2}{*}{ Nesting sand } & \multirow{2}{*}{ Bacterial isolates } & \multicolumn{3}{|c|}{ Average inhibition zone (mm) } & \multirow[b]{2}{*}{ Cloacal fluid $\mathrm{D}$} \\
\hline & & Cloacal fluid A & Cloacal fluid B & Cloacal fluid $\mathrm{C}$ & \\
\hline 1. & Escherichia coli & 6.56 & 6.53 & 6.52 & 6.54 \\
\hline 2. & Escherichia coli & 6.44 & 6.15 & 6.72 & 6.84 \\
\hline 3. & Escherichia coli & 6.97 & 6.225 & 6.32 & 6.61 \\
\hline \multicolumn{2}{|c|}{ Total average $(\mathrm{mm})$} & 6.66 & 6.3 & 6.52 & 6.66 \\
\hline 4. & Salmonella spp. & 6.87 & 6.63 & 6.63 & 6.43 \\
\hline 5. & Salmonella spp. & 6.55 & 6.3 & 6.28 & 6.78 \\
\hline 6. & Salmonella spp. & 6.5 & 6.66 & 6.53 & 6.53 \\
\hline \multicolumn{2}{|c|}{ Total average $(\mathrm{mm})$} & 6.64 & 6.53 & 6.48 & 6.58 \\
\hline 7. & Bacillus spp. & 7.61 & 7.75 & 7.86 & 8.19 \\
\hline 8. & Bacillus spp. & 7.66 & 7.64 & 7.76 & 7.88 \\
\hline 9. & Bacillus spp. & 7.84 & 8.14 & 7.2 & 8.39 \\
\hline \multicolumn{2}{|c|}{ Total average (mm) } & 7.703 & 7.84 & 7.61 & 8.15 \\
\hline
\end{tabular}

Previous studies in flatback, green, hawksbill, and loggerhead sea turtles recorded that cloacal fluids had antifungal properties, but the defenses mechanism against fungi colonies did not last more than a few days. Plants are also known to contain peptides that can protect against fungi during natural conditions. Whereas, the mucus of other organisms, such as fish, amphibians, and humans have been proven to contain antifungal and antibacterial properties (De Andrés et al. 2014; Bezy et al. 2015). Insects, such as Genus of Drosophila have been also shown to produce antifungal peptides (De Andrés et al. 2014) and antibacterial peptides (Wu et al. 2018). Antibacterial peptides have been used by South African clawed frog (Xenopus laevis) to defend against bacteria and the pathogenic fungus Batrachochytrium dendrobatidis, which is commonly known to cause Chytridiomycosis, a major lethal disease in frogs (Gammill et al. 2012). Several fish species such as eel (Anguilla spp.), Asian swamp eel (Monopterus albus), and marine stingray were reported using antibacterial mechanisms through their skin which also have potential effects against pathogenic bacteria such as Salmonella spp. (Bragadeeswaran and Thangaraj 2011; Vennila et al. 2011; Nurtamin at al. 2016; Hilles et al. 2018). Moreover, common freshwater fish such as carp also developing antibacterial properties on epidermal skin which related to their health status and protection mechanism against pathogenic microorganisms (Dash et al. 2018; Reverter et al. 2018; Kumari et al. 2019). Similar peptide mechanisms also have been found in human amniotic fluids as an important part of the immune response to microbial infection in the amniotic cavity (Kang et al. 2019). The best method to scientifically understand the mechanism in which peptides could potentially inhibit microorganisms is through bacteria. Unlike eukaryotes, bacterial membranes contain negatively charged phospholipids on the outer surface, moreover, the peptides which have positively charged terminals could bind to the negatively charged bacterial membranes, to disrupting the membrane structure and causing depolarization of the cell (Somma et al. 2020). Other theories include the binding of peptide nisins to the fatty acyl proteoglycan anchor in the bacterial membrane, where it can diffuse throughout the rest of the membrane (Vestby et al. 2020). This similar strategy is used by plant defensins (Sathoff et al. 2019). It remains questionable how exactly the presence of peptides kills the bacterial cells, however, it has been hypothesized that it is caused by the depolarization of the bacteria cell itself, creates several holes in the membranes which lead to cell content escape, degradation of the cell walls or disturbing membrane functions, or even damaging intracellular targets after internalization of peptides. Unlike conventional antibiotics, it is more difficult for bacteria to build up resistance mechanisms to these peptides because they would have to reorganize their membrane structures, which is considered a costly defense for microorganisms (Somma et al. 2020).

Whereas, antibiotics affect microorganisms in five ways: (i) inhibiting cell wall synthesis, (ii) disrupting the cell membrane function, (iii) inhibiting protein synthesis, (iv) inhibiting nucleic acid synthesis, or (v) through antimetabolites (Nassar et al. 2019). Moreover, antibiotics can be activated through killing (bactericidal) or inhibiting the growth of cells (bacteriostatic). Although most of the antibiotics purchased over the drug stores, today are categorized as semisynthetic, the original antibiotics used to treat various diseases existed naturally, and their properties are what synthetic antibiotics are derived from. For example, Avermectin is an important antibiotic in both human and veterinary medicine, but is produced as secondary metabolite found in the common soil bacterium namely Streptomyces avermitilis (Quinn et al. 2020). Cloacal fluid, which has mucous-like in consistency, previously has been hypothesized that it plays roles in reducing egg speed as they are dropped in natural nesting chamber, also cloacal fluid allows sand to stick to the outside of the eggshell and prevent sand and other contaminants from moving and filling up the spaces between eggs, causing air pockets. Olive ridleys estimated drop $250-500 \mathrm{~mL}$ of fluid on a single nest, potentially providing natural protection if antimicrobial properties are present (Keene 2012). Since, olive ridleys are one of the smallest sea turtle species, it is possible that larger species secrete more fluid to protect their eggs against pathogenic microorganisms. 
In conclusion, eventually, this study becomes preliminary report that demonstrated antimicrobial properties in the cloacal fluids of olive ridley sea turtles in Banyuwangi, Indonesia. Future studies should be conducted using different methods for detecting the cloacal fluid molecular compounds and which proteins that mostly play role as antimicrobial properties. In addition, future studies should be conducted using other bacteria and fungi found in the nesting sand and eggs. The presence of antimicrobial properties could be used to preliminary methods in creating natural antibiotics applicable in the nesting chamber to prevent microorganism contamination and globally increase hatchling success and scientifically have a greater impact on sea turtle conservation efforts as endangered species.

\section{ACKNOWLEDGEMENTS}

The authors would like to thank all members of Banyuwangi Sea Turtle Foundation and laboratory assistants in Department of Veterinary Microbiology, Universitas Airlangga, Indonesia for their help during the investigation and paper preparation. This work was supported financially by the Penelitian Internal Universitas Airlangga, Indonesia (no.1408/UN3/2019).

\section{REFERENCES}

Abbas F, Hafeez-ur-Rehman M, Ashraf M, Iqbal KJ, Andleeb S, Khan BA. 2020. Mucus properties of Chinese carp and Indian carp: Physical barrier to pathogens. Iran J Fish Sci 19 (3): 1224-1236. DOI: 10.22092/ijfs.2019.119394.0

Abreu-Grobois FA, Morales-Mérida BA, Hart CE, Guillon J, Godfrey MH, Navarro E, Girondot M. 2020. Recent advances on the estimation of the thermal reaction norm for sex ratios. Peer J 8: 1-28. DOI: $10.7717 /$ peerj.8451.

Adel M, Safari R, Soltanian S, Zorriehzahra MJ, Esteban MA. 2018. Antimicrobial activity and enzymes on skin mucus from male and female Caspian kutum (Rutilus frisii kutum Kamensky, 1901) specimens. Slov Vet Res 55 (4): 235-243. DOI: 10.26873/SVR-4402018.

Bezy VS, Valverde RA, Plante CJ. 2015. Olive Ridley sea turtle hatching success as a function of the microbial abundance in nest sand at Ostional, Costa Rica. PLoS One 10 (2): 1-24. DOI: 10.1371/journal.pone.0118579.

Blasi MF, Migliore L, Mattei D, Rotini A, Thaller MC, Alduina R. 2020. Antibiotic resistance of Gram-negative bacteria from wild captured Loggerhead sea turtles. Antibiotics 9: 162-173. DOI: 10.3390/antibiotics 9040162

Booth DT, Dustan A. 2018. A preliminary investigation into the aerly embryo death syndrome (EEDS) at the world's largest green turtle rookery. Plos One 13 (4): 1-13. DOI: 10.1371/journal.pone.0195462.

Bragadeeswaran S, Thangaraj S. 2011. Hemolytic and antibacterial studies on skin mucus of eel fish, Anguilla anguilla Linnaues, 1758. Asian J Bio Sci 4 (3): 272-276. DOI: 10.3923/ajbs.2011.272.276.

Candan O, Candan ED. 2020. Bacterial diversity of green turtle (Chelonia mydas) nest environment. Sci Total Environ 720: 1-10. DOI: 10.1016/j.scitotenv.2020.137717.

Caron AGM, Thomas CR, Berry KLE, Motti CA, Ariel E, Brodie JE. 2018. Ingestion of microplastic debris by green sea turtles (Chelonia mydas) in the great barrier reef: validation of a sequential extraction protocol. Mar Pollut Bull 127: 743-751. DOI: 10.1016/j.marpolbul.2017.12.062.

Dash S, Das SK, Samal J, Thatoi HN. 2018. Epidermal mucus, major determinant in fish health: a review. Iran J Vet Res 19 (2): 72-81. DOI: $10.22099 / \mathrm{ij} v r .2018 .4849$.
Dawson A. 2011. Antibacterial and antifungal properties of loggerhead (Caretta caretta) and flatback (Natator depressus). B.S. Honors [Thesis]. Griffith University, Gold Coast, AUS.

De Andrés E, Gómara B, González-Paredes D, Ruiz-Martín J, Marco A. 2016. Persistent organic pollutant levels in eggs of leatherback turtles (Dermochelys coriacea) point to a decrease in hatching success. Chemosphere 146: 354-361. 10.1016/j.chemosphere.2015.12.021.

Gammill WM, Fites JS, Rollins-Smith LA. 2012. Norepinephrine depletion of antimicrobial peptides from the skin glands of Xenopus laevis. Dev Comp Immunol 1: 19-27. DOI: 10.1016/j.dci.2011.12.012

Gifari T, Elfidasari D, Sugoro I. 2018. The effects of contaminant microorganism towards Chelonia mydas eggs hatchery result in Pangumbahan Green Sea Turtles Conservation, Sukabumi, Indonesia. Biodiversitas 19 (4): 1207-1212. DOI: 10.13057/biodiv/d190404.

Gleason FH, Allerstorfer M, Lilje O. 2020. New Newly emerging diseases of marine turtles, especially sea turtle egg fusariosis (SEFT), caused by species in the Fusarium solani complex (FSSC). Mycology 1: 111. DOI: 10.1080/21501203.2019.1710303.

Hilles AR, Mahmood S, Kaderi MA, Hashim R. 2018. Review about the importance of skin mucus from asian swamp eel (Monopterus albus). MOJ Proteom Bioinform 7 (5): 152-153. DOI: 10.15406/mojpb.2018.07.00249

Hoh DZ, Lin YF, Liu WA, Sidique SNM, Tsai IJ. 2019. Nest microbiota and pathogen abundance impact hatching success in sea turtle conservation. bioRxiv. DOI: 10.1101/776773.

Hoh DZ, Lin YF, Liu WA, Sidique, SNM, Tsai IJ. 2020. Nest microbiota and pathogen abundance in sea turtle hatcheries. Fungal Ecol 47: 111. DOI: 10.1016/j.funeco.2020.100964.

Kang X, Dong F, Shi C, Liu S, Sun J, Chen J, Li H, Xu H, Lao X, Zheng H. 2019. An update data repository of antimicrobial peptides. Sci data 6: 148-158. DOI: 10.1038/s41597-019-0154-y.

Keene EL. 2012. Microorganism from sand cloacal fluid and eggs of Lepidochelys olivacea and standart testing of cloacal fluid antimicrobial properties. [Thesis]. Purdue University, USA.

Kumari S, Tyor AK, Bhatnagar A. 2019. Evaluation of the antibacterial activity of skin mucus of three carp species. Intl Aquat Res 11: 225239. DOI: 10.1007/s40071-019-0231-z.

Lee Y, Bilung LM, Sulaiman B, Chong, YL. 2020. The antibacterial activity of fish skin mucus with various extraction solvents and their in-vitro evaluation methods. Int Aquat Res 12:1-21. DOI: 10.22034/IAR(20).2020.670998

Nassar MSM, Hazzah WA, and Bakr WMK. 2019. Evaluation of antibiotic susceptibility test results: how guilty a laboratory could be? J Egypt Public Health Assoc 94 (4): 1-5. DOI: 10.1186/s42506-0180006-1.

Neves MSC, Moura CCM, Oliveira LG. 2015. Mycobiota from the eggs, nest and stillbirths of Eretmochelys imbricate Linneus 1766 (Testudines: Cheloniidae) in Pernambuco State, Brazil. Afr J Microbiol Res 9 (17): 1195-1199. DOI: 10.5897/AJMR2015.7389.

Nurtamin T, Nurman RY, Hafizah I. 2016. Antibacterial activity of eel (Anguilla spp.) mucus against Salmonella typhi. Indon Biomed J 8 (3): 179-182. DOI: 10.18585/inabj.v8i3.231.

Peay KG, Kennedy PG, Talbot JM. 2016. Dimensions of biodiversity in the earth mycobiome. Microbiome 14: 434-447. DOI: 10.1038/nrmicro.2016.59

Pelegrini PB, Perseghini del Sarto R, Silva ON, Franco OL, Grossi-de-Sa MF. 2011. Antibacterial peptides from plants: hat they are and how they probably work. Biochem Res Intl 1: 1-9. DOI: $10.1155 / 2011 / 250349$.

Phillott A, Parmenter CJ. 2012. Anti-fungal properties of sea turtle cloacal mucus and egg albumen. Mar Turtle Newsl 134: 17-21.

Quinn GA, Banat AM, Abdelhameed AM, Banat IM. 2020. Streptomuces from traditional medicine: sources of new innovation in antibiotic discovery. J Med Microbiol 69: 1040-1048. DOI: 10.1099/jmm.0.001232.

Rafferty AR, Reina RD. 2012. Arrested embryonic development: a review of strategies to delay hatching in egg-laying reptiles. Proc Royal Soc Biol Sci 279: 2299-2308. DOI: 10.1098/rspb.2012.0100.

Raj VS, Fournier G, Rakus K, Ronsmans M, Ouyang P, Michel CD, Costes B, Farnir F, Leroy B, Wattiez R, Melard C, Mast J, Lieffrig F, Vanderplasschen A. 2011. Skin mucus of Cyprinus carpio inhibits cyprinid herpesvirus 3 binding to epidermal cells. Vet Res 42 (92): 19. DOI: 10.1186/1297-9716-42-92. 
Reverter M, Bontemps NT, Lecchini D, Banaigs B, Sasal P. 2018 Biological and ecological roles of External fish mucus: A Review. Fishes 3 (41): 1-19. DOI: 10.3390/fishes3040041.

Rosado-Rodriguez G, Maldonado-Ramirez SL. 2016. Mycelial fungal diversity associated with the leatherback sea turtle (Dermochelys coriacea) nest from Western Puerto Rico. BioOne 15 (2): 265-272. DOI: $10.2744 / C C B-1217.1$.

Sathoff AE, Velivelli S, Shah DM, Samac DA. 2019. Plant defensin peptides have antifungal and antibacterial activity against human and plant pathogens. Phytopathology 109: 402-408. DOI: 10.1094/PHYTO-09-18-0331-R.

Smyth CW, Sarmiento-Ramirez JM, Short DPG, Dieguez-Uribeondo J, O'Donnell K, Geiser DM. 2019. Unraveling the ecology and epidemiology of an emerging fungal disease, sea turtle egg fusariosis (STEF). PLoS Pathog 15 (5): e1007682. DOI: 10.1371/journal.ppat.1007682.

Somma AD, Moretta A, Cane C, Cirillo A, Duilio A. 2020. Antimicrobial and antibiofilm peptides. Biomolecules 10: 1-15. DOI: 10.3390/biom10040652.
Soslau G, Spotila JR, Chun A, Yi S, Weber KT. 2011. Potentially lethal bacteria in leatherback turtle eggs in the wild threaten both turtles and conservationists. FEMS Microbiol Lett 410: 101-106. DOI: 10.1016/j.jembe.2011.10.018.

Torow N, Marsland BJ, Hornef MW, Gollwitzer ES. 2017. Neonatal mucosal immunology. Immunology 10 (1): 5-17. DOI: 10.1038/mi.2016.81.

Tyor AK, Kumari S. 2016. Biochemical characterization and antibacterial properties of fish skin mucus of fresh water fish, Hypophthalmichthys nobilis. Int J Pharm Pharm Sci 8 (6): 132-136.

Vennila R, Kumar KR, Kanchana S, Arumugam M, Vijayalakshmi S, Balasubramaniam T. 2011. Preliminary investigation on antimicrobial and proteolytic property of the apidermal mucus secretion of marine stringrays. Asian Pac J Trop Biomed S239-S240. DOI: 10.1016/S2221-1691(11)60162-7.

Vestby LK, Gronseth T, Simm R, Nesse LL. 2020. Bacterial biofilm and its role in the pathogenesis of disease. Antibiotics 9 (59): 1-29. DOI: 10.3390/antibiotics9020059.

Wu Q, Patocka J, Kuca K. 2018. Insect antimicrobial peptides, a mini review. Toxins 10: 1-17. DOI: 10.3390/toxins10110461. 